\title{
SAÚDE É POLÍTICA. A PANDEMIA DA COVID-19 É POLÍTICA apontamentos para o debate
}

\author{
Notes for debate \\ Heloisa Maria Mendonça de Morais \\ http://orcid.org/oooo-ooo1-8244-66o1 \\ UFPE, médica e Doutora em Saúde Coletiva \\ Raquel Santos de Oliveira \\ http://orcid.org/oooo-0oo2-6189-1543 \\ UFPE, cirurgiã-dentista e Doutora em Odontologia
}

HEALTH IS POLITICS. THE COVID-19 PANDEMIC IS POLITICS

\section{RESUMO}

O ensaio explora a importância da política para ampliar o entendimento acerca da pandemia da Covid-19 em sua origem e em seus desdobramentos. Apresenta uma breve síntese sobre a desigualdade social do Brasil para contextualizar como ela é agravada pela condição pandêmica. Aponta constrangimentos da política de saúde anterior à crise atual, sobretudo o subfinanciamento do sus, argumentando que o golpe parlamentar ocorrido, em 2016, no país onerou essa condição. Indica, ainda, o papel de grupos econômicos que desestruturam o sus por dentro do sistema. Ao conjunto dessas razões, atribui o ambiente favorável que o coronavírus encontrou no Brasil e que favoreceu sua difusão por todo o território. Finalmente, chama atenção para a falta de coordenação das ações contra a pandemia por parte do ente federativo e apresenta algumas fragilidades do sistema de saúde que ganharam visibilidade com a pandemia.

Palavras-chave: Covid-19; Pandemia; Sistema Único de Saúde; Desigualdade social.

\begin{abstract}
This essay explores the importance of politics to broaden the understanding of the COVID-19 pandemic at its origin and at its developments. It presents a brief synthesis of Brazil's social inequality to put in context how it is aggravated by the pandemic. This essay also points out health policy constraints prior to the current crisis, especially the underfunding of sus (Brazil's public funded health system), arguing that the parliamentary coup that occurred in 2016 in the country burdened this condition. Further, this study indicates the role of economic groups that disrupt sus from within the system. All these reasons are provided as to having led to the favorable environment that the Coronavirus found in Brazil, allowing its spread throughout the territory. Finally, this article draws attention to the lack of coordinated actions against the pandemic by the Federal Government and presents some weaknesses of the health system that have become explicit with the pandemic.
\end{abstract}

Keywords: Covid-19; Pandemics; Unified Health System; Social inequity. 
Se a PANDEMia dA CoVid-19 VEM TRANSformando o modo de agir das pessoas em todos os lugares, não menor tem sido seu impacto sobre as ideias respeitantes à ocorrência das doenças. Assim, o pensamento que vem se consolidando nos últimos seis meses, no Brasil e no mundo, é o resultado do jeito de viver e interpretar a realidade pandêmica, embora ainda não seja possível prever o quanto falta descobrir no tocante a esse inusitado fenômeno. Desse modo, o que vamos apresentar neste manuscrito é o registro do que temos lido, ouvido, observado, pensado e, por que não, até sentido, sob os efeitos desta insólita experiência em relação à qual ainda se estão plasmando as primeiras ideias científicas.

Por oposição a essa incerteza, entretanto, as observações reunidas, até então, se constituem em fortes indícios que permitem reafirmar o pressuposto enunciado no título acima indicado. Tomando Hanna Arendt como inspiração, podemos dizer que "a política é uma necessidade imperiosa para a vida do indivíduo e da sociedade"; a política, ao tomar para si a tarefa e o objetivo de garantir a vida no sentido mais amplo, se justifica por sempre ter existido onde os homens convivem num sentido histórico-civilizatório (ARENDT, 2004, p. 45-46).

Nessa direção, o agir de homens que praticaram a ciência médica vem à lembrança. Rudolf Virchow, um médico alemão que viveu no século XIX (1821-1902), bem conhecido por bacteriologistas e patologistas por seus estudos sobre a hanseníase, defendeu que "a medicina é uma ciência social e a política nada mais é do que a medicina em grande escala" (ROSEN, 1985, p. 79).

Em 1848, no período revolucionário que ocorreu em alguns países da Europa, Virchow esteve nas barricadas de Berlim e lutou contra o governo alemão, afirmando que, "se a enfermidade é a expressão da vida individual sob condições desfavoráveis, as epidemias devem ser indicativas de perturbações importantes na vida das massas" (virchow apud 
ROSEN, 1985, p. 82). E, ao asseverar que essas perturbações eram de natureza social e econômica, ensinava que "as epidemias não ocorriam por si mesmas e elas só ocorriam em razão da situação social quando as pessoas vivem por longo tempo sob condições anormais" (VIRCHOW apud ROSEN, 1985, p. 83).

No cenário do que foi, em território europeu, uma das mais importantes revoluções burguesas do século XIX, Hobsbawm (1978, p. 540) refere-se ao episódio de 1848 como "uma revolução social", ao entender que ela mobilizou todas as classes sociais e os trabalhadores, exigindo uma nova sociedade e um novo Estado. Pois bem, naquelas lutas estiveram os médicos reformadores alemães, e entre eles Virchow, fazendo com que o movimento que ajudou a engendrar entrasse para a história.

Mais de um século depois, o médico italiano Giovanni Berlinguer propõe que as causas das doenças podem ser fisiógenas e antropógenas. Se, para as primeiras, os fatores de origem biológica são as causas principais, para as segundas, predominam condições não preexistentes na natureza, mas decorrentes da intervenção humana. E o autor recorre ao enfoque da historicidade, para explicar por que umas e outras causas determinam, em diferentes sociedades e de modo distinto, a ocorrência das doenças (BERLINGUER, 1978, p. 104-112).

A partir da Revolução Bacteriológica do século XIX, à medida que o conhecimento científico foi avançando, surgia um novo paradigma para a compreensão sobre a origem das doenças. Ao mesmo tempo, e em decorrência dos processos históricos e sociais que a humanidade atravessou desde então, pode-se demonstrar que as causas fisiógenas têm perdido importância, enquanto as antropógenas ganham proeminência.

Daí que não deve causar estranhamento a afirmativa que dá título a este despretensioso ensaio. Tanto antes como agora, o que subsiste é a necessidade imperiosa de se conhecer a realidade e explicá-la, para só depois tentar transformá-la. Até porque "não é a consciência que determina a vida, é a vida que determina a consciência" (MARX; ENGELS, 2009, p. 32).

Portanto, entender a emergência da Covid-19 no Brasil e o modo como ela vem acontecendo e sendo combatida, bem como as interpretações, até então, disponíveis para esses acontecimentos, supõe aceitar que o processo de objetivação da realidade é mediado por relações sociais que os homens estabelecem entre si. "E são essas relações que explicam as ideias e as instituições que eles criam" (MARX; ENGELS, 2009, p. 12). Ideias e instituições que fazem leis, definem e executam políticas.

Em atenção, pois, ao convite da Estudos Universitários (EUs) para discorrer sobre um tema entre os tantos sugeridos por seu corpo de editores - ante o complexo de problemáticas originado pela pandemia da Covid-19 -, entendemos que, não sendo esta uma revista especialmente destinada a profissionais de saúde, talvez uma contribuição adequada consistisse em apresentar aspectos que consideramos mais relevantes para uma abordagem do que se denomina "um problema de saúde pública”.

E essa não é uma expressão do senso comum. Há requisitos bem estabelecidos a serem preenchidos para sua 
significação. A magnitude do problema é avaliada por indicadores de saúde específicos, os quais mensuram sua força sobre a morbidade e a mortalidade das pessoas acometidas, passando pelo impacto sobre as condições de vida da população, assim como pela disponibilidade de métodos, técnicas e tecnologias de intervenção, preventivos e/ou curativos, com potencialidade para sanar seus efeitos lesivos. Por si, esse arcabouço seria suficiente para justificar que a Covid-19 se constitui, sim, em um grave problema de saúde pública.

Sob essa perspectiva, é imprescindível contar com um sistema de saúde bem-estruturado e resolutivo para assegurar os resultados das intervenções adequadas. Indaga-se, então, qual sistema seria esse e de qual sistema de saúde brasileiro estamos falando frente às necessidades impostas pela ocorrência da Covid-19.

Porém, como uma resposta possível a essa questão está longe de ser unívoca, se impôs às autoras esboçar o pano de fundo sobre o qual pretendem justificar um dos argumentos condutores deste ensaio, segundo o qual a pandemia e seus desdobramentos (de toda ordem) exacerbam o que se mantém constante, desde sempre: a desigualdade estrutural brasileira.

Mas não sem antes registrar que a crise que assombra o país não é nova, em suas múltiplas dimensões. Nos últimos seis meses, todavia, desmediu-se em todas elas. E em suas manifestações política, econômica, sanitária, social, ambiental e moral, a pandemia converteu-se em um monstro indomável, o nosso lobo contemporâneo, numa analogia ao animal que, na Idade Média, por ocasião da
Peste Bubônica, tinha sua imagem associada ao de principal inimigo do homem.

\section{A DESIGUALDADE ESTRUTURAL DO BRASIL}

Por certo, o tema que se constitui em nosso ponto de partida, a desigualdade estrutural, é um dos mais visitados entre autores brasileiros do campo das ciências sociais. Embora de modo diferenciado, conforme cabalmente demonstrado por Souza (2018, p. 158-173), ao analisar a temporalidade dos enfoques predominantes nessa abordagem. Desse modo, no início dos anos 1980, o tema perdeu visibilidade e, entre 1980-1995, a questão distributiva saiu das manchetes, para ressurgir na década de $2000-$ 2010, quando as pesquisas domiciliares teriam começado a mostrar uma queda da desigualdade.

Mas esse resultado aparente será desnudado pelos resultados da pesquisa empreendida por Souza (2018), ao apontar que os dados do Imposto de Renda da Pessoa Física não revelam nenhuma tendência de redução da desigualdade desde meados dos anos 2000. Em seu minucioso trabalho, ele chama atenção, ainda, além dessa alternância periódica do último meio século - em que ora se enfatiza a questão distributiva, ora essa permanece relegada ao esquecimento, cedendo espaço à ênfase conferida à pobreza -, para o fato de que, "em 2013, o milésimo mais rico apropriou-se de $10 \%$ da renda total, o centésimo mais rico recebeu quase $23 \%$, e o décimo mais rico, como um todo, obteve pouco mais de 51\%" (souzA, 2018, p. 337-338). Assim, "as mudanças mais radicais e positivas dos últimos tempos ocorreram na base 
ou no meio da pirâmide social, e não no topo" (souzA, 2018, p. 223). O fato de as mudanças não haverem incidido na fatia da riqueza apropriada pelos mais ricos é considerado pelo autor como uma característica particular da desigualdade no país (souzA, 2018, p. 217-223).

Por uma perspectiva mais longa, podemos partir de um lugar quase comum ao afirmar que a história do Brasil sempre carregou essa marca da desigualdade social. É possível dizer que, desde o segundo período republicano, com a urbanização do país e a introdução do desenvolvimentismo como projeto nacional, as diferenças de renda não pararam de crescer (BARBOSA, 2012, p. 29). Situação que, de modo geral, não se altera até o fim do século $\mathrm{xx}$.

Portanto, é uma evolução histórica de longo prazo essa condição, mediante a qual "a pobreza e a desigualdade, ao concentrarem a renda, a riqueza, o poder e a cultura nas mãos de poucos, têm definido os caminhos pelos quais a sociedade se reproduz" (BARBOSA, 2012, p. 30). Caminhos esses que têm se caracterizado, entre outros aspectos, pelo acesso desigual a bens sociais e a serviços básicos em todo o território. A saúde entre eles.

Essa trajetória tortuosa persiste nas décadas que iniciam o século xxI, ainda que algumas mudanças na distribuição de renda tenham sido indiscutivelmente demonstradas (souzA, 2018; BARBOSA, 2012; GIMENEZ, 2O08; POCHMANN, 2001). É essa realidade que permite a Barbosa e Amorim afirmarem:
Dado que a distribuição da propriedade não foi alterada; que a estrutura tributária brasileira é regressiva; que os programas de transferência de renda do governo federal são de pouca monta quando comparados ao PIB ou ao orçamento do Tesouro Nacional, ainda que se mostrem relevantes do ponto de vista do orçamento das famílias atendidas; que o mercado de trabalho continua apresentando taxas de não-contribuição à previdência superiores a 50\%; e que o nível educacional médio do trabalhador é baixo, apesar dos avanços alcançados; não é possível imaginar que o Brasil viveu uma redução sensível da desigualdade ou que a queda da mesma possa ser acelerada, nos próximos anos, sem tocar nessas questões fundamentais (BARBOSA: AMORIM, 2013, p. 13)

A questão posta nesses termos aponta para um debate central no Brasil: o quanto se fala sobre a pobreza e se silencia sobre a desigualdade. E, como as ações políticas e econômicas para alterar uma e outra (des)ordem são distintas, isso significa que programas e políticas destinados à redução da primeira não implicam, necessariamente, mudanças na segunda.

De um modo que, mesmo nesse período recente, a questão social permanece equivalendo ao atendimento dos pobres e à sua secular pobreza, circunstância em que, a depender da métrica do momento, pode-se adequar o número de beneficiários ou o valor dos benefícios à disponibilidade de recursos ${ }^{1}$. Tudo isso em detrimento de políticas sociais rigorosas em sua execução, com definição orçamentária e, por conseguinte, expressivas enquanto parcelas do fundo público

1 Exemplo atual e contundente é a métrica oscilante do atual governo para definir e redefinir o "auxílio emergencial" para setores da população atingidos pelas ignominiosas taxas de desemprego no cenário da pandemia. 
destinadas ao gasto social (GIMENEZ, 2008, p. 179-180).

No plano político, esse debate será retomado por ocasião dos dois governos Lula (2003-2010) e do primeiro governo Dilma (2011-2014). Mais do que o debate, esse período ficou marcado pela efetivação de políticas de distribuição de renda, com o aumento real do salário mínimo, com o Bolsa Família, e com programas que promoveram o acesso à educação superior para os pobres e garantiram a construção de habitação popular para milhares de pessoas. Essas políticas, se não tiveram efeito sobre o padrão de distribuição de riquezas, conseguiram impactar os indicadores de pobreza a um ponto nunca antes experimentado na história do país.

Avaliando a provisoriedade desses resultados e sua dependência das coalizões de governo em cada momento histórico é que setores amplos da sociedade têm proposto a adoção de um conjunto de reformas estruturais - agrária, urbana, tributária e nas relações de trabalho. Esses setores defendem que atacar a raiz dos persistentes e inaceitáveis padrões de desigualdade seria o caminho definitivo para viabilizar as transformações pelas quais a sociedade clama - sobretudo as classes sociais que pagam o maior tributo frente a uma inexorável realidade -, condenadas, de outro modo, a perenemente adiarem-se.

Retomaremos essa matéria mais adiante neste manuscrito, numa tentativa de conferir visibilidade ao que ela contém de mais atual. Entrementes, a questão que não perde atualidade seria indagar por que a insistência na mesma tecla. Por que não se impõe outro leitmotiv para expressar a preocupação dominante nas análises sobre saúde da população? Provavelmente, pela indisponibilidade de um denominador mais potente para dar conta da relação causa-efeito quando se trata de compreender e explicitar a díade condições de vida-condições de saúde.

Ainda que, neste texto, a desigualdade estrutural tenha sido tratada apenas pontualmente, com a finalidade de contextualizar a reflexão, é sob a perspectiva de o quanto ela determina e condiciona o padrão de intervenção estatal, no que tange às políticas sociais, que vamos tratar a política de saúde em suas versões, antes e durante a pandemia da Covid-19.

\section{A POLÍTICA DE SAÚDE ANTERIOR À PANDEMIA}

Já se vão 32 anos desde a criação do sus pela Constituição Federal de 1988 (doravante, CF 1988). O sistema foi criado para ser universal e igualitário, isto é, deveria assistir igualmente a todas(os) as(os) brasileiras(os). E só agora, na vigência da pandemia, com o Brasil ocupando destacado lugar nas taxas de morbidade e mortalidade entre os países de todos os continentes ${ }^{2}$, essa universalidade passa a ser reivindicada por diversas instâncias da sociedade brasileira: pelos poderes Executivo e Judiciário; pelas câmaras de representação municipais, estaduais e federais; pela mídia de todos os formatos (impressa, falada e digital);

2 Segundo a OMS, em 17/09/2020, o Brasil ocupava a terceira posição em número de casos - 4.445.386 - atrás dos EUA e da Índia; e a segunda em número de óbitos - 134.935 -, atrás dos EUA (OMS, 2020). 
por empresários e empregadores de todos os portes; por trabalhadores urbanos e rurais; pelos usuários do sistema; enfim, por todos.

E, mais que reclamada, a universalidade passa a ser compreendida enquanto estratégia fundamental no combate à pandemia, numa expressão quase unívoca que proclama: "Ai do país e de sua gente, não fora o sus, ainda que com todos os problemas desse sistema”. E mesmo os estratos possuidores de riqueza, aqueles que, por cabal incivilidade, declaravam não precisar do sus, porquanto seus planos de saúde lhes ofertam o melhor da assistência médica, devem ter agora boas razões para, finalmente, compreender que o sistema universal é uma instituição que protege as pessoas para além da necessidade imediata da assistência médico-hospitalar.

No entanto, o sus persiste ameaçado hoje, como sempre, desde o momento histórico de sua promulgação. Ao mesmo tempo que, no Brasil, eram dados os primeiros passos na direção do que poderia vir a ser um Sistema de Seguridade Social, nos países capitalistas centrais os anos 1990 acenavam com outras tendências para as políticas econômicas e sociais, em oposição às políticas públicas universalistas.

Tendo em vista as forças conservadoras locais que apoiaram os governos dos anos 1990, o ideário liberal encontrou no Brasil um terreno fértil para sua consolidação. Aquelas mesmas forças passaram, então, a manifestar fortes resistências ao projeto da Seguridade Social proposto na CF 1988, no interior do qual estão a saúde, a previdência social e a assistência social.

Assim, os anos 1990, uma década perdida para a economia brasileira, segundo Pochmann (2001, p. 19-38), vão se caracterizar enquanto um período muito conflituoso para o desenvolvimento do sus. De um lado, esses anos coincidiram com os primeiros esforços para mudar o modus operandi do Ministério da Saúde, o responsável, finalmente, pela implementação da nova política de saúde.

E não foi pouco esse trabalho, resultando progressivamente na remontagem institucional daquele que viria a ser o órgão federal ao qual competia formular o conjunto das mudanças necessárias para a garantia de uma saúde universal. Do

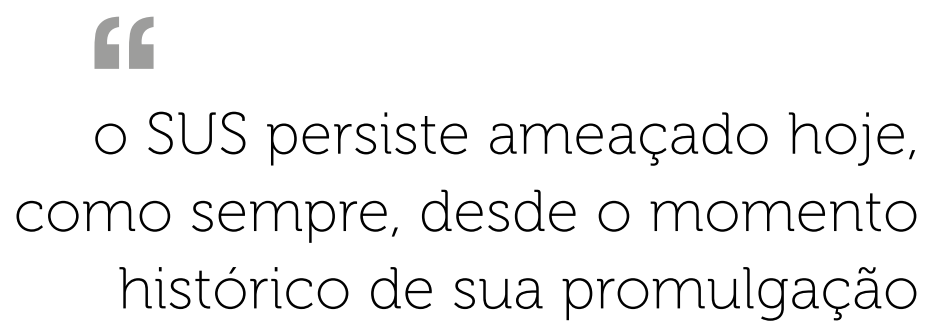


outro lado estavam as pressões para fazer retroceder o arcabouço legal do sistema de saúde recém-criado, e impedir as transformações que eram propugnadas.

Porém, como a mobilização das forças sociais pró-sus foi muito intensa, as vozes oponentes não conseguiram elidir as proposições constitucionais contidas no parágrafo 196 da CF. Contudo, elas se organizaram desde então, inclusive via representação parlamentar, para conformar um setor privado ativo e vigilante em relação a seus propósitos de crescimento e de participação nas decisões concernentes à política de saúde.

Como resultado desses conflitos, o sus, desde a origem, não será um sistema único de saúde, mas um arranjo organizativo com componentes públicos e privados, "um sistema misto que combina um direito social universal com um mercado de bens e serviços de saúde privados" (TEIXEIRA; PINHO, 2018, p.17).

Ainda assim, como um dos maiores sistemas públicos universais de saúde, havia acumulado, até 2015, um conjunto inquestionável de resultados exitosos: as ações da Estratégia de Saúde da Família, com cobertura estendida a algo em torno de $62,5 \%$ da população (BRASIL, 2020); a cobertura vacinal universal da população infantil em níveis protetores; a queda progressiva da mortalidade infantil com erradicação e controle de doenças infecciosas; o programa de prevenção e controle de DST/Aids, exemplar para outros países; a diminuição da prevalência de tabagismo na população geral (hoje, a prevalência de fumantes é de 10\%); um vigoroso programa de transplantes com fila única (é nos hospitais do sus que se realizam 90\% dos transplantes do país); a oferta de hemodiálise a mais de $100 \mathrm{mil}$ brasileiros portadores de doença renal crônica; a expansão de uma política de saúde mental responsável pela desinstitucionalização da atenção psiquiátrica; a difusão do programa de farmácia popular, que fornece medicamentos aos portadores de doenças crônicas; a política descentralizada de sangue e hemoderivados, que tem salvado milhares de vidas, em todas as regiões do país, pelo trabalho dos hemocentros; a rede de urgência e emergência, incluindo-se o Samu, que é uma referência para toda a população etc.

Os milhões de procedimentos anuais que a efetivação desses programas requer somente são suportados pela atuação de milhares de trabalhadores de saúde que, por uma cultura institucional baseada no compromisso com as finalidades de um setor público universal, têm papel nuclear na estruturação e no fortalecimento do sus. Impossível nos alongarmos aqui, e é até desnecessário, para justificar a importância da educação permanente - estratégia central dessa cultura -, enquanto fundamento do que se denomina trabalho em saúde.

Para que um compromisso desse porte se realizasse com eficácia e eficiência muito maiores que as registradas, seria necessário que a União, nas últimas três décadas, houvesse provido a gestão do sus com muito mais recursos financeiros do que os até hoje repassados. Também seria preciso que esses recursos fossem direcionados ao incremento do que de fato é público no sistema.

Dados do IBGE, em 2017, indicam que o Brasil destinou 9,2\% do seu PIB para gastos com saúde, patamar que nos 
aproximaria dos países capitalistas centrais. Desse valor, entretanto, apenas 3,9\% é gasto público, o que é incompatível com a condição de um sistema universal e é, ao mesmo tempo, uma das evidências de um sistema privatizado. Diferentemente do que propala o Banco Mundial, a eficiência na gestão não prescinde de recursos financeiros.

Essa questão tem merecido especial atenção dos analistas da política de financiamento, os quais vêm demonstrando, à exaustão, a necessidade de uma mudança radical na redefinição do teto de gastos para que o Estado brasileiro possa custear o cuidado com a saúde da população.

Os estudos disponíveis mostram como, em três décadas, o sus vem acumulando perdas sucessivas de recursos. Desde o não cumprimento dos 30\% do Orçamento da Seguridade Social (oss) para seu financiamento, como está nos Atos das Disposições Constitucionais Transitórias (CF 1988), até as mudanças introduzidas, a partir de 2015, pela Emenda Constitucional 86. Mas "nada foi pior que as regras da Emenda Constitucional 95/2016, que introduziu o teto de gastos, para agravar o subfinanciamento do SUs" (FUNCIA; OCKÉREIS, 2018, p. 85).

Efetivamente, Moretti e outros (2020) demonstraram que, entre 2018 E 2020, as perdas acumuladas de recursos somaram R\$ 22,5 bilhões. Em termos per capita, essa retirada significou uma redução de $\mathrm{R} \$ 594,00$ para $\mathrm{R} \$ 583$, 00 (a preços de 2019), o que diminuiu o gasto também como proporção da receita corrente líquida de $15,77 \%$ para $13,54 \%$. Ou seja, o sus, que deveria receber $\mathrm{R} \$ 250$ bilhões/ ano (30\% do oss), deverá ter neste ano de 2020 R $\$ 125$ bilhões.

Enquanto o sus persiste nessa travessia de carências, nas últimas duas décadas o mercado de bens e serviços privados expandiu-se fisicamente, modernizou-se de um ponto de vista tecnológico e ganhou complexidade gerencial, qualificando-se para disputar espaço crescente na oferta de serviços. Assim sendo, cuidou em se difundir por todo o território nacional, prestando serviços ao sus e/ou aos planos e seguros.

Seus representantes também se organizaram para concorrer no âmbito legítimo de representação política da ordem institucional. Adentraram os corredores dos poderes constituídos, praticaram $l o b b y$, e tentam, por expedientes rotineiros e por todos os meios possíveis, assegurar seus espaços para a captura do fundo público (MORAIs et al., 2019). Eles fazem isso, por exemplo, ao usufruírem de linhas de crédito especiais nos bancos públicos brasileiros, e ao se beneficiarem das escandalosas renúncias e desonerações fiscais, que lhes são atribuídas pelos poderes executivos nas distintas instâncias de governo.

Como se não bastasse, entidades que se apresentam como comprometidas com a atenção universal e com a igualdade chancelam, sistematicamente, em nome do sus, expedientes de exclusão em suas práticas de atendimento, tolerando filas inaceitáveis e negando vagas ou procedimentos médicos imprescindíveis à assistência da população.

Resulta que, hoje, o sus continua apresentando enorme grau de dependência assistencial de um setor privado declaradamente financeirizado, cujas intenções 


\section{o SUS continua apresentando enorme grau de dependência assistencial de um setor privado declaradamente financeirizado}

finalísticas estão mais vinculadas aos movimentos do mercado, em detrimento dos princípios que orientaram a criação do sistema há três décadas.

Como parte das mudanças na arquitetura desse setor privado, grandes grupos econômicos se cruzam por dentro do sus, atuando na comercialização de planos de saúde, na movimentação de uma desmedida rede de farmácias e drogarias, em hospitais, centros médicos e serviços de apoio diagnóstico, ou, ainda, em parte daqueles que, sob o epíteto de organizações sociais, aparecem entre as maiores empresas do Brasil (MORAIs et al., 2018).

Assim, ao eclodir a pandemia da Covid-19, o Brasil reunia condições por demais favoráveis para se destacar negativamente nos indicadores que iriam mensurar sua ocorrência: pelo menos um terço da população (7o milhões de brasileiros) sobrevivendo em situação de pobreza, sob condições habitacionais e sanitárias incompatíveis com a saúde e a vida, além de um sistema de saúde que, desde 2016, vinha acentuando suas fragilidades porque solapado, pelo governo e pelos empresários da saúde, na estruturação de suas políticas e nas bases de seu financiamento. É como se o país estivesse a escrever sua "crônica de uma crise sanitária anunciada” (WERNECK; CARVALHO, 2020).

De quais condições estamos falando? A qual realidade objetiva estamos nos referindo? Neste ponto, tratamos de conceder à política sua relevância para $\mathrm{o}$ ordenamento social, isto é, em todo esse rol de acontecimentos recentes que abordamos até aqui. Assim, o processo político que culminou com o golpe parlamen$\operatorname{tar}^{3}$, que, em 2016, destituiu a presidenta Dilma Roussef, deve ser lembrado no sentido que lhe foi conferido pelo Prof. Wanderley Guilherme dos Santos (2017): um "truque esperto, [que] consiste precisamente em valer-se dos mecanismos

3 Embora em seu último livro em vida o autor utilize apenas a expressão "golpe parlamentar" para designálo enquanto "fenômeno que se inscreve na história das democracias representativas de massa", no Brasil, o debate travado pela sociedade civil no período terminou por consolidar outra nomeação - golpe empresarialmidiático, judicial e parlamentar. E que nos parece bastante adequada aos fatos tais como eles ocorreram na cena política, lembrando ainda dos não menos decisivos componentes externos, tais como as denominadas "guerras híbridas" (кORYBKO, 2018). 
de operação normais das instituições em favor de objetivos ilegítimos".

Por conseguinte, em combinação com Santos (2017), podemos declarar que teriam sido também ilegítimas as alterações por leis, portarias e resoluções, ou por outros instrumentos quaisquer, as quais, de 2016 até 2018, passaram a se opor ao arcabouço formal do sus.

Naquele cenário, a primeira declaração do Sr. Ricardo Barros, nomeado Ministro da Saúde pelo Sr. Michel Temer, foi a de que "o Brasil não cabia dentro do sus" (COLLUCI, 2016). Para, a seguir, mencionar os planos populares de saúde como a resposta oficial para a alegada incompatibilidade. Consequentemente, foi entre perplexidade e indignação que, em todo o país, o movimento sanitário recebeu essa manifestação, já pressagiando os dias difíceis que estariam por vir.

Na sequência, o programa de austeridade fiscal implantado pelo novo governo, apoiado pelos empresários, e que materializou o projeto ultraneoliberal como eixo condutor das decisões políticas, tratou de ajustar a pauta das políticas sociais aos ditames da área econômica.

Ademais, a austeridade fiscal, para além de promover cortes de recursos nos gastos primários, aumenta a demanda por serviços públicos de saúde, e, decerto, no período que se seguirá à pandemia. Serão incontáveis as pessoas que tiveram seus tratamentos (clínicos e/ou cirúrgicos) de doenças crônicas interrompidos; também serão incontáveis aquelas que não puderam ser atendidas em decorrência de outros estados mórbidos. Somam-se a essa conjuntura os efeitos do desemprego, que têm levado parte das famílias à perda dos planos empresariais ou à impossibilidade de seguirem comprando planos no mercado. Por conseguinte, haverá menos recursos para maiores e mais prementes necessidades de saúde da população.

Por essas razões, se impõe retornar ao Prof. Wanderley Guilherme dos Santos, quando ele assinala que: "A cerimônia do golpismo parlamentar contemporâneo mantém quase intocados os ritos costumeiros, mas obedece a roteiro especial na proposição de leis e na utilização de rotinas conhecidas para extensa subversão política, econômica e social da ordem destituída" (sANTOS, 2017, p. 16).

\section{AUSÊNCIA DE UMA POLÍTICA PARA CONTROLAR A PANDEMIA}

Em 3 de fevereiro de 2020, o Ministério da Saúde decretou a ocorrência da Covid-19 uma Emergência em Saúde Pública de Importância Nacional. Em 11 de março de 2020, a Organização Mundial da Saúde declarou a situação de pandemia. Essas condições pressupunham a coordenação ativa das ações sanitárias que deveriam combater o problema, contando com a cooperação das esferas do governo, nos âmbitos nacional e estadual.

Contudo, o intenso debate que, desde aquele momento, os profissionais de saúde, juntamente com outros observadores da situação, têm travado contradiz essa expectativa. E, se há uma univocidade na discussão, é que uma das faltas mais importantes, até hoje, em todo o processo de condução das ações políticas e sanitárias, tem sido a ausência de uma coordenação nacional. Essa questão foi agudizada pela passagem (até o momento) de três ministros pela gestão do Ministério da Saúde, o que 
imprimiu ao órgão distintas orientações técnico-políticas e administrativas para o combate de uma mesma doença (LIMA; PEREIRA; MACHADO, 2020).

Não fora a firmeza de vários governadores estaduais, que tomaram para si o esforço de combate à Covid-19, legitimados por decisão do Supremo Tribunal Federal, que decidiu, inclusive, sobre a autonomia local para as deliberações pertinentes ao isolamento social, as medidas de combate certamente teriam sido mais retardadas.

O resultado foi que um conjunto de problemas ligados à (des)organização social do país foi exacerbado pela pandemia: as consequências da desigualdade estrutural, seja quanto aos grupos sociais mais acometidos, seja com relação à gravidade da evolução clínica dos que adoeceram tendo em vista o acesso dificultado à rede assistencial; as fragilidades da atenção primária, que não respondeu à busca ativa dos cidadãos para os cuidados relacionados à prevenção; a falta de leitos e de condições infraestruturais, para a atenção complexa nos insuficientes hospitais existentes; a carência generalizada de insumos (testes, máscaras, aventais, medicamentos, respiradores, ambulâncias etc.), para o acompanhamento $\mathrm{e}$ tratamento dos adoecidos; a ausência de meios de proteção para os trabalhadores de saúde; entre outros problemas. Esse conjunto de carências está presente em todo o país, destacadamente nas regiões Norte e Nordeste.

A inexistência de profissionais de saúde qualificados para lidar com a complexidade da Covid-19 constituiu-se em um nó crítico relevante, que deve ser imputado ao Governo Federal, no conjunto das consequências decorrentes da extinção do programa Mais Médicos.

Entretanto, as amplas e abrangentes iniciativas da sociedade civil, em locais onde o Estado quase nunca chega para solucionar carências de toda ordem, tiveram efeito mobilizador entre moradores de favelas e de comunidades pobres, evitando, assim, o colapso social em larga escala.

Enquanto o país convive com esses acontecimentos, que esgarçam seu tecido 
social, desde 2016 avançam as tentativas de desmonte político e econômico do sus, que continua sendo disputado por projetos oponentes para as políticas sociais ainda em vigência no país. Disputado, entenda-se, pela aparência de legalidade que possibilita a compra e venda de serviços por meio de seus programas de atenção. Inclusive, há disputas até no âmbito da atenção primária e da vigilância epidemiológica, que, até há pouco tempo, eram tidas como reservas cativas do Estado, isto é, como espaço de baixo interesse para os negócios na saúde, áreas em que os indicadores de saúde já demonstraram resultados tão animadores quando o Estado toma para si, com prontidão, a prestação do cuidado.

Neste momento, está em discussão o Projeto da Lei Orçamentária Anual do governo, que destinará para os gastos com saúde, em 2021, valores abaixo dos de 2020. "O que já era insuficiente, ficou ainda pior a partir de 2018, e, para 2021, o Governo Federal e parte do Congresso Nacional pretendem dar o 'golpe fatal' contra a saúde da população, mediante a redução de $\mathrm{R} \$ 35$ bilhões do sus, pois ainda será um ano de despesas extraordinárias decorrentes da pandemia" (FUnCIA et al., 2020). Nessa direção, enquanto agentes públicos, desconsideram que o orçamento para o país só adquire legitimidade à luz dos princípios constitucionais.

$\mathrm{Na}$ contramão de mais essa ofensiva, o Conselho Nacional de Saúde entregou ao Congresso Nacional a petição pública "O sus merece mais em 2021", com 50 mil assinaturas, com o objetivo de sensibilizar deputados e senadores, para garantir a continuidade do orçamento emergencial para a saúde em 2021.

Fatos como esses expressam, de um lado, o "fanatismo fiscal que está levando o país ao caos social" (FUnCia et al., 2020), mas, ao mesmo tempo, também expressam a resistência dos movimentos sociais na defesa do patrimônio cívico que é o sistema de saúde universal brasileiro.

Mesmo quando as respostas à pandemia parecem ser fundamentalmente técnicas, essas soluções não se materializam fora do espaço da política.É o terreno da tecno-política. Aliás, o título deste texto já indicava não haver resposta possível à pandemia que não seja política.

\section{REFERÊNCIAS}

ARENDT, H. O que é política? Rio de Janeiro: Bertrand Brasil, 2004.

BARBOSA, A. F. (org.). O Brasil real: a desigualdade para além dos indicadores. São Paulo: Outras Expressões, 2012.

BARBOSA, A. F.; AMORIM, R. C. Desafios para o enfrentamento da desigualdade no Brasil. In: FONSECA, A.; FAGNANI, E. (org.). Políticas sociais, desenvolvimento e cidadania. São Paulo: Editora Fundação Perseu Abramo, 2013. BERLINGUER, G. Medicina e política. São Paulo: Cebes-Hucitec, 1978.

BRASIL. Ministério da Saúde. Secretaria de atenção primária à saúde. Relatório de cobertura da atenção básica. Disponível em: https://egestorab.saude.gov.br/paginas/acessoPublico/relatorios/relHistoricoCoberturaAB.xhtml. Acesso em: 12 set. 2020 .

COLLUCI, C. Tamanho do SUS precisa ser revisto, diz novo ministro da Saúde. Folha de S. Paulo, São Paulo, ano 96, n. 35.821, 17 maio 2016. Disponível em: http://www1.folha.uol.com.br/cotidiano/2016/05/1771901-tamanho-do-sus-precisa-ser-revisto-diz-novo-ministro-da-saude.shtml. Acesso em: 15 ago. 2020. 
CONSELHO NACIONAL DE SAÚDE. O SUS merece mais em 2021. Petição pública "Você vai deixar o SUS perder mais R $\$ 35$ bilhões em 2021?" encaminhada à Comissão Externa do Enfrentamento à Covid-19 da Câmara dos Deputados. Brasília, 9 set. 2020. Disponível em: http://conselho.saude.gov.br/ultimas-noticias-cns/1297-peticao-publica-voce-vai-deixar-o-sus-perder-mais-r-35-bilhoes-em-202. Acesso em: 12 set. 2020.

FUNCIA, F; OCKÉ-REIS, C. Efeito da política de austeridade fiscal sobre o gasto público federal em saúde. In: ROSSI, P.; DWECK, E.; OLIVEIRA, A. L. (org.). Economia para poucos: impactos sociais da austeridade e alternativas para o Brasil. São Paulo: Autonomia Literária, 2018.

FUNCIA, F. R.; OCKÉ-REIS, C.; MORETTI, B. "Fanatismo fiscal” está levando o Brasil ao caos social; SUS merece mais em 2021. In: Centro Brasileiro de Estudos da Saúde - Cebes [homepage], Rio de Janeiro, 8 fev. 2020. Disponível em: http://cebes.org.br/2020/og/funcia-ocke-e-moretti-fanatismo-fiscal-esta-levando-brasil-ao-caos-social-sus-merece-mais-em-2021/. Acesso em: 27 ago. 2020.

GIMENEZ, D. M. Ordem liberal e a questão social no Brasil. São Paulo: LTr, 2008.

GONÇALVES, R. Desenvolvimento às avessas: verdade, má-fé e ilusão no atual modelo brasileiro de desenvolvimento. Rio de Janeiro: LTC, 2013.

HOBSBAWM, E. J. Las revoluciones burguesas. Barcelona: Guadarrama/Punto Omega, 1978.

KORYBKO, A. Guerras híbridas: das revoluções coloridas aos golpes. São Paulo: Expressão Popular, 2018.

LIMA, L. D.; PEREIRA, A. M. M.; MACHADO, C. V. Crise, condicionantes e desafios de coordenação do Estado federativo brasileiro no contexto da Covid-19. Cadernos de Saúde Pública, Rio de Janeiro, v. 36, n. 7, jul. 2020.

MARX, K.; ENGELS, F. A ideologia alemã. São Paulo: Expressão Popular, 2009.

MORAIS, H. M. M.; ALBUQUERQUE, M. S. V.; OLIVEIRA, R. S.; CAZUZU, A. K. I.; SILVA, N. A. F. Organizações Sociais da Saúde: uma expressão fenomênica da privatização da saúde no Brasil. Cadernos de Saúde Pública, Rio de Janeiro, v. 34, n. 1, 2018.

MORAIS, H. M. M.; VIEIRA-DA-SILVA, L. M.; OLIVEIRA, R. S. A coalizão dos empresários da saúde e suas propostas para a reforma do sistema de saúde brasileiro: retrocessos políticos e programáticos (2014-2018). Ciência \& Saúde Coletiva, Rio de Janeiro, v. 24, n. 12, p. 4479-4488, 2019.

MORETTI, B.; OCKÉ-REIS, C.; ARAGÃO, E.; FUNCIA, F.; BENEVIDES, R. Mudar a política econômica e fortalecer o SUS para evitar o caos. In: Instituto de Saúde Coletiva da Universidade Federal da Bahia [homepage], Salvador, 30 maio 2020. Disponível em: http://www.isc.ufba.br/artigo-mudar-a-politica-economica-e-fortalecer-o-sus-para-evitar-o-caos/. Acesso em: 20 ago. 2020.

OMS (Organização Mundial da Saúde) = WHO (World Health Organization). WHO Coronavirus Disease (COVID-19) Dashboard. 13 set. 2020. Disponível em: https://covid19.who.int. Acesso em: 18 set. 2020.

POCHMANN, M. A década dos mitos: o novo modelo econômico e a crise do trabalho no Brasil. São Paulo: Contexto, 2001.

ROSEN, G. De la policía médica a la Medicina Social. México: Siglo Veintiuno Editores, 1985.

SANTOS, W. G. A democracia impedida: o Brasil no século XXI. Rio de Janeiro: FGV Editora, 2017.

SOUZA, P. F. Uma história da desigualdade: a concentração de renda entre os ricos no Brasil, 1926-2013. São Paulo: Hucitec/Anpocs, 2018.

TEIXEIRA, S. F.; PINHO, C. E. S. Liquefação da rede de proteção social no Brasil autoritário. Revista Katálisis, Florianópolis, v. 21, n. 1, p. 14-28, jan./abr. 2018.

WERNECK, G. L.; CARVALHO, M. S. A pandemia de Covid-19 no Brasil: crônica de uma crise sanitária anunciada. Cadernos de Saúde Pública, Rio de Janeiro, v. 36, n. 5, maio 2020.

Texto de autoras convidadas. Recebido em: 18 set. 2020 .

MORAIS, Heloisa Maria Mendonça de; OLIVEIRA, Raquel Santos de. Saúde é política. A pandemia da Covid-19 é política - apontamentos para o debate. Estudos Universitários: revista de cultura, Recife, v. 37, n. 1/2, p. 16-29, dez. 2020. ISSN Edição Digital: 2675-7354. 